\title{
THE IMPLEMENTATION OF TRAINING AND EDUCATION PROGRAM FOR THE HEADMASTER CANDIDATES AT EDUCATION QUALITY GUARANTY INSTITUTION (LPMP) LAMPUNG (EVALUATIVE STUDY OF KIRKPATRICK AND HAMMOND MODEL)
}

\author{
Fardarita1 and Ahmad2 \\ SMAN 5 Bandar Lampung ${ }^{1}$, Universitas Gajayana Malang ${ }^{2}$ \\ Soekarno-Hatta Street (by-pass) Sukarame, Bandar Lampung ${ }^{1}$, Campus Mertojoyo Street Blok L. Merjosari, \\ Malang ${ }^{2}$

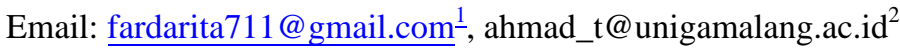

\begin{abstract}
This research was aimed at investigating the reaction, learning achievement, behavior changing, and the effect of training and education program for headmaster candidates by paying attention on institutional, instructional, and behavioral dimension. The research was conducted at the Education Quality Guaranty Institution Lampung. The evaluative qualitative research was applied in this research using blended model of evaluative training model of the Four Levels and the three dimensions cube model. The data was collected by giving questionnaire, observation, interview, documentation, and headmaster candidates' test results. The result of the research revealed that the purpose of the program was formulated based on the participants' need, considering the clear qualification of the purpose formulation and the outcome could be observed, the program design described the continuous application strategy dealt with the competence structure, the realization of time, the training and education needed to be improved especially in the use of method, time, management, and the quality of the consumption, the participants' behavior changing after going back to their working place, the result of the training and education program impacted very much in increasing the school quality, and the appointment of the headmasters considered their competence. As the result of the evaluation, it can be concluded that the headmaster candidates training and education program is categorized good and recommended to be continued with some improvements.
\end{abstract}

Keywords: program evaluation, training and education, Kirpatrick, Hammond

\section{INTRODUCTION}

The efforts to improve school quality continue to be encouraged, one of which is through the education and training of headmaster candidates, because in terms of the competencies possessed by the headmasters are still considered very weak in managing the institution. Based on the mapping results of The Development and Empowerment of Headmaster (LPPKS) and The Education Quality Guaranty Institutions (LPMP) in 2010, the average abilities of headmasters nationally are $85 \%$ character aspect, $74 \%$ administrative, $74 \%$ entrepreneurship, $72 \%$ supervision, and $63 \%$ social. In general, new competency mastery so far has reached $76 \%$. The percentage shows that there is still a need for a prolonged method and strategy to expand the competency mastery of the headmasters which are $24 \%$ low so that all headmasters hold complete competency mastery, Siswandari (2013: 1).

The mastery of this ability is in line with the headmaster' duty, as an administrator who cannot be separated from leadership, regulating, supervising, and being responsible for the progress of the school being led. According to Stronge, Richard, and Catano (2013: 4), headmasters must build schools, headmaster, and school teachers. According to Wahyosumidjo (208: 82), the headmaster collects central forces that are the driving force of school life. The headmaster must understand the tasks and functions for the sake of the school, be concerned for staff, students, and other school neighbors. The school as a compiling organization, the headmaster asks for expertise and competency to support the school as well as the training of headmaster candidates organized by 
the Education Quality Guaranty Institution. The Training and Education Programs for Headmaster Candidates need to be carried out to increase the number of participants in the Training and Education Programs for Headmaster Candidates organized by the Education Quality Guaranty Institution.

The evaluation of the training and education programs is carried out by referring to the steps of developing implementation instructions and technical systems for learning or upgrading candidates for education leaders by assessing: (1) The level of how the upgrading and learning participants of educational leaders participate in addressing program objectives, (2) To what extent the upgrading and learning participants of educational leaders is in sharing knowledge, changing attitude, increasing knowledge, and skills, (3) To what extent behavior changes occur because the upgrading and learning participants of educational leaders have attended training and education programs, and (4) Provision of learning outcomes or upgrading the education leaders can improve the quality of work, which is measured based on the competency structure that must be achieved by the participants during the learning activities and upgrading of candidates of educational leaders.

Related to the description above, the source of the criteria in determining the success of the evaluation of training and education programs for headmaster candidates is the the guideline for implementing the education and training of headmaster candidates which refers to Minister of National Education Regulation Number 13 of 2007 concerning Headmasters' Competence. The program evaluatin criteria are described based on Kirkpatrick's blended evaluation model and Cube 3 Dimensions which are outlined in the form of component tables, evaluated aspects, indicators, and criteria.

The purposes of this study are to find out how the government organizes training for headmaster candidates is, how the teaching system process provides learning experience according to the participants' perceptions is, how changes in knowledge, attitudes, and skills of the participants participating in the training is, to know the instructional system carried out in learning, to know how the institution holds training, to get information about behavior changes after the training and educatin programs at school, and to know the impact of training for headmaster candidates in providing benefits to improve the quality of work and quality of school.

Kirkpatrick's evaluation model is a comprehensive evaluation model which can be applied to evaluate various fields of study that can help evaluators to gradually evaluate the implementation of training, which is oriented to management. While the 3 Dimensional Cube, according to Worten et. al. (1987: 66-67), is a model that helps evaluators to evaluate learning programs in detail by looking at learning programs through 3 dimensions: Behavior knowledge, attitudes, and skills.

According to Patton (1990: 14), "qualitative methods typically produce a wealth of detailed information," can be interpreted that qualitative methods usually produce a wealth of detailed information. The views of Denzin and Lincoln (2009: 5), that qualitative research means many things at the same time. They have a focus of attention with a variety of paradigms.

According to Ghony dan Almanshur (2012: 76), that qualitative approach provides space for researchers to study a system and the relationship of all activities in the system that can be seen totally, not partially.

\section{METHOD}

Research of training and education programs evaluation for headmaster candidates is oriented towards the value and benefits of the availability of a program. The program's evaluation research approach uses qualitative and quantitative approachers. A qualitative approach is used to obtain data from interview, observation, field record, and documentation study. The quantitative approach is used to process and analyze the participants' attitudes towards the implementation of the learning 
program for headmaster candidates, and to analyze the test results before and after attending the training program.

The method used was program evaluation by appkying Kirkpatrick's blended model (evaluating training programs), consisting of level 1 reaction, level 2 learning, level 3 behavior, and level 4 result, and Cube 3 Dimensions of Hammond which include behavior, instruction, and institution. In this study, both models were combined and complementary.

The institution was combined with Kirkpatrick's four level 2 learning to find out the extent to which the role of the learning organization of headmaster candidates contributed to the success of the participants. In level 3 behavior, according to Kirkpatrick (2005: 3-21), the aim is to find out how changes in participants' attitudes after returning to school, applying their experience after attending education and training. Level 4 is the result or impact of learning outcomes of headmaster candidates in improving school conditions, school productivity, quality of work, and the formation of teamwork in schools that will have an overall impact on the results of school evaluation monitoring.

The method applied in this program evaluation study relates to the training and education programs aspects. Each aspect uses a different approach in gathering information as outlined in the program evaluation design compared to the success criteria.

To determine the success rate of each component, the evaluation is based on category. To determine the category, according to Azwar (2012: 147) because the category is relative, the extent of the interval that includes each desired category can be determined subjectively as long as the determination is within limits of reasonableness and common sense. The criteria for success in evaluating the program refer to Azwar's opinion, which is based on five levels of categorization (ordinal), placing individuals into groups whose position is tiered according to a continuum based on measured attributes. The research success criteria used are as follows:

1. If the value of $X \geq 80$ is very good/very appropriate/very adequate that the percentage of achievement of the indicatior is very fulfilled.

2. If the value of $60 \leq X<80$ is good/appropriate/adequate that the percentage of achievement of the indicator is fulfilled.

3. If the value of $40 \leq X<60$ is sufficient enough that the percentage of achievement of the indicator is sufficiently fulfilled.

4. If the value $20 \leq X<40$ is less appropriate/inadequate that the percentage of achievement of the indicator is not fulfilled.

5. If the value of $X<20$ is very less/very inappropriate/very inadequate that the percentage of achievement of the indicator is very poorly met.

Determination of the success of the training program for headmaster candidates is decided if each component of the program gets a score above $70 \%$ of achievement of the evaluation results fulfilled. The research design in this study can be seen in the following figure. 
Blended

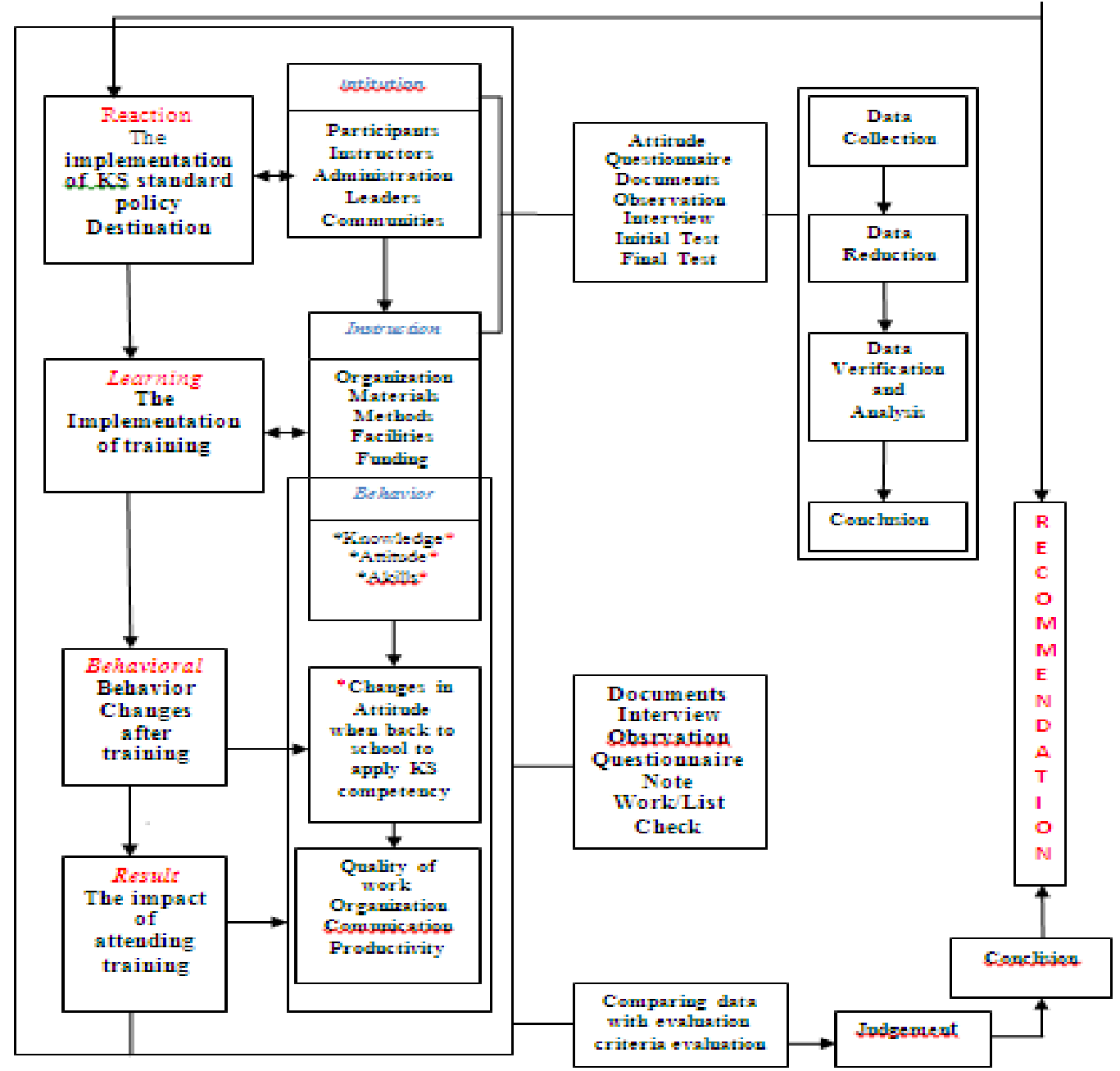

Information:

*Changes in attitude after learning

*Changes in attitude upon returning to school

Figure 1. Research Design

\section{RESULTS}

Evaluation results are in accordance with standard policies, headmasters master personal, managerial, supervision, entrepreneurial, and social competencies. The headmasters' competency demands have a set of knowledge, attitudes, and skills that can be experienced, mastered in carrying out their professional duties. The following are the results of the study:

Reaction is described in two aspects, namely: 1) The purpose of the training program for headmaster candidates as the participants, to fulfill the learning experience in order to qualify to be the headmaster who has very appropriate competency standards, 2) Orientation of the needs of personality, managerial, supervision, enrepreneurship, and social is very adequate. Institution consists of: Teacher / instructor is a master trainer who has obtained very adequate qualifications and certification, and Studen / training participants are in accordance with academic selection procedures in adequate regulations, 3) Administrators who assist management of training by 
preparing teacing materials or modules, arranging schedules and time by coordinating with the local education office, preparing an assessment on service learning 1, on the job learning, and in service learning 2, learning activities, education and training facilities including consumption, adequate, 4) Educational specialis in this case the institution leader or facilitator in directing the potential of training participants adequately, 5) Community which is defined as support for participants participating in training is very adequate.

Learning includes: Training organization which has competency structure with adequate competency achievement, Instructions to the achievement of learning objectives including content is interpreted as adequate material and curriculum training program models, the material is prepared in accordance with adequate systematic competencies. Method, clarity of objectives relevance to needs, systematic material, timeliness, assessment, and achievement of objectives are adequate. Mastery of the material of the teacher's abilities, relevance of material with objectives, methods of media, language, answering questions, quality, style and neatness, cooperation between facilitators, are all adequate. Learning facilities, the accuracy of instructors choosing media, strategies and supporting tools, the selection of learning infrastructure, are very adequate. Funding uses State Budget (APBN) / Regional Government Budget (APBD), but this research does not discuss it.

Behavior assessment is carried out in learning, there is an adequate document of participants' assessment result. The assessment of participants implementing the result of education and training at school is considered adequate, there are documents of school headmaster in teacher performance, the results of school monitoring and evaluation are adequate. Behavior of headmaster candidates from SMAN 7 Bandar Lampung with adequate result needs to be improved again. SDN 1 Way Hui, Jatimulyo, South Lampung has adequate result, but it needs to be improved. SMAN 1 Sekampung Udik, East Lampung is very adequate, maintained. SDN 1 Simba Waringin, Central Lampung is adequate, but it needs to be improved. SMKN 1 Tegineneng, Pesawaran is adequate, perfected. SDN 5 West Metro is adequate, but it needs to be improved. SMAN 2 Menggala Tulang Bawang is adequate, but it needs to be improved. SMAN 1 Pagelaran Pringsewu is adequate, maintained.

Result impact of participants participating in training for quality work, school quality, and increased productivity are stated in the teacher performance appraisal assessment document, teacher competency test, school rating, shool quality, school type, school EDS result, teacher achievement notes before and after training, and the number of applicants in the school. The results of the evaluation of the training at SMKN 7 Bandar Lampung are adequate and needing to be improved. SDN 1 Way Hui, South Lampung is adequate, greatly enhanced. SMAN 1 Sekampung Udik, East Lampung Timur is adequate, improved again. SDN 1 Simba Waringin, Central Lampung is adequate, but it needs to be improved again. SMKN 1 Tegineneng, Pesawaran is adequate, but it needs to be improved. SDN 5 West Metro is adequate, but it needs to be improved. SMAN 2 Menggala, Tulang Bawang is adequate, but it needs to be improved. SMAN 1 Pagelaran, Pringsewu is very adequate, maintained.

\section{Assessment of instructional and institutional is adequate.}

Training program model is adequate. Assessment of pre-test and post-test improved. Assessment of participant attitudes obtained from instructors and organizers is average good. Changes in the attitude of headmaster candidates in workplaces in eight districts / cities in Lampung are, headmaster candidates (CAKEP) of SMKN 7 Bandar Lampung are in good behavior, good quality of the school. CAKEP of SDN 1 Way Hui, South Lampung changes in work behavior are good, but the school quality still needs to be developed. CAKEP of SMAN 1 Sekampung Udik, East Lampung changes in work behavior are good, the school quality is good.

88 | JISAE. Volume 6 Number 1 February 2020. 
CAKEP of SDN 1 Simba Waringin, Central Lampung changes in good work behavior, good school quality. CAKEP of SMKN 1 Tegineneng, Pesawaran offers changes in work behavior very well, but the school quality still needs to be developed. CAKEP of SDN 5 West Metro, Metro City changes in good work behavior, but the school quality needs to be developed. CAKEP of SMAN 2 Menggala, Tulang Bawang changes work behavior very well, the school quality is good. CAKEP of SMAN 1 Pagelaran, Pringsewu changes in work behavior are very good and the shool quality is also very good.

The implementation of the learning system as well as testing the candidates for school leaders organized by the Education Quality Guaranty Institution according to the stages implemented show good result. However, ther are still sub-components that need to be reviewed and improved. The learning system of school leader candidate can answer the need of candidates to meet competency standard. Increased attitudes needed by school leader candidates look good and have increased. The quality and achievement of the school with the learning system that has been followed by the school leader candidats can achieve the values of benefits that greatly affect the school's performance and work environment. Specifically described as follow:

\section{Headmaster Competency Standard Policy}

Program evaluation answers the problem of how government policies implement learning systems and testing of shool leader candidates. The limitation of evaluation on this evaluation is the goal of the training program for headmaster candidates oriented to the competency needs of participants, the implementation of training provides a learning experience to achieve the headmaster competency standard.

The results of policy program evaluation relating to the teaching program process and the testing of school leader candidates are carried out by accredited institutions according to their authority, and the regional education office is responded by headmaster candidates in improving the competency standard of school leaders. This shows that the training program for headmaster candidates is very important to be carried out continuously in preparing teachers as competent school leaders.

Analysis of headmaster competency standard shows the proper rationalization of the importance of this program as one of the government's commitments in improving the competence of headmasters. The reaction aspect of the participants answering the implementation of candidate training program for shool leaders in providing participants' learning experiences is through the use of various resources. Whether the training participants are satisfied with the implementation of the training followed, there are two main dimensions in the implementation aspects of the training program, namely the reaction and institution dimensions in the implementation of learning, the reaction to assess participants' perceptions of the training being followed in this case the intituition. The evaluation results show that the training of headmaster candidates is organized with systematic planning clearly programmed, achieving goals by answering the competency problems of participant. The evaluation model used is to accommodate the opinios of participants on the expected implementation of the training of headmaster candidates.

The learning dimensions of the headmaster candidates' training program for the achievement of clear instruction include the presentation of material, selection of methods, use of the media, use of infrastructure, time allocation, and sources of funds, while the dimensions of the training program for headmaster candidates include the role of the instructor / facilitator, the role of the the participants, the role of the manager / organizer of training, and the role of the environment. This evaluation assesses the dimensions as a whole. From each dimension, there are several components that are assessed by both participants and training instructor. The use of time allocation to discuss learning material by the instructor is considered good, but it needs to be 
reviewed to be improved, this together with participants's assessment of time allocation as a supporting tool found in learning.

The training method chosen by the instructor to provide participants with a good learning experience can still be improved so that it is more perfect. Supporting infrastructure related to the provision of consumption during the training is considered good by the participants. All components of the learning and instruction aspect of that dimension are considered good or adequate. However, what needs to be improved by the trainers in their participation involves the participants in discussing the training material, which is considered good by the participants. This assessment is continuous with the participant's assessment of time allocation as a means of supporting the implementation of training in the learning dimension. All components in the learning aspect of two dimensions are considered appropriate.

However, there are indications that still need to be improved by the instructor in his role involving training participants, especially in discussing material on learning. The role of the facilitator and training provider needs to increase their role in involving participants, needing to improve monitoring for participants. Based on the result of these assessments, it can be concluded that it should be noted that the right time allocation to discuss material that requires demonstration, simulation, or practicum, so that instructors and facilitators can provide learning experiences as planned in the design of the study program for the headmaster.

\section{The Implementation of Training Programs for Headmaster Candidates}

Evaluation of aspects of learning and instruction answers about how training programs are designed, and program models are developed. This model is considered as a learning system approach, and accommodates the competencies expected by participants based on those needs, so the final goal can be formulated after participants participate in the training program for headmaster candidates, participants have the principal's competency standard. The model of the training program for headmaster is considered appropriate as a training program model, but in this evaluation, it is indicated that the model needs to be refined so that it can guide the implementation of training programs, by clearly describing each component contained by the model. Based on the results of the assessment, the objectives of the training and education programs have been formulated by taking into account the requirements for formulating clear, measurable objectives, training results can be observed through the instructional analysis process so that the training program has a competent structure with complete structured and tiered objectives

The training program for headmaster candidates answers the problem of how education and training programs are designed to reach the competencies of participants. Evaluation of the design of the program requires a clear picture of the procedure, strategies implemented to teach participants, and creating learning activities that utilize resources and are scheduled. The design of the education and training program includes the structure of competencies, the design of the education and training program developed in the form of a matrix, and a curriculum which is the implementation of scheduling.

The criteria for evaluating the assignments of the training program participants are designed with reference to the competency structure, but they still need to be improved considering the suitability of the scope, completeness, and depth of tasks with the measured competencies considered to be optimized. The results of the participant's learning assessment before the training and after the training are improved, this indicates that the learning experience is well mastered by the participants, but it still needed to be improved to be very good.

\section{Attitude Changes of Participants after Training Back to School}

Evaluation of behavioral aspects answers problems about how changes in the attitude of training participants during the course of learning in class and changing attitudes after returning to 
work. The product of the education and training program is a learning experience gained during the training. The real manifestation of participants' learning experiences is applied in the form of changes in work attitudes in their workplaces, the application of personality, managerial, supervision, entrepreneurial and social competencies in advancing schools. Improving the performance of prospective school principals has implications for work performance and good quality of schools.

The results of the assessment indicate that the overall education and training participants from each district representing their schools have made changes to their workplaces which are considered good, but they still need to be improved for the better. This is indicated by the duties and authority given by superiors to prospective school principals from teachers to vice principals and other fields that are closely related to the task of increasing school management. Overall, the results of the assessment of changes in work attitudes of prospective school principals or former training participants based on evaluations are considered good / adequate.

\section{Impact of Training Headmaster Candidates}

Evaluation of the results of the prospective headmaster answers the problem of the impact of the training of candidates for school leaders on work performance, quality of work, work productivity of candidates for school leaders and school performance. The impact of participating in the training of prospective school principals for participants from each district representing their schools is a very good improvement.

The results of the assessment indicate that headmaster candidates have adequate learning experience in participating in training programs. This is evidenced by the increased work performance and school achievement achieved by the headmaster candidates with the duties and authority recommended by the headmaster to assist the headmaster in organizing the school as the vice principal, and continued with the appointment as headmaster. Of the eight districts evaluated there are four principals who havebeen appointed, and four deputy principals, this component is considered adequate.

\section{CONCLUSION}

In general, the research policy of implementing government training for headmaster candidates is considered adequate. The implementation of education and training in providing participants' learning experiences is organized with systematic planning, clearly programmed, achieving goals answering participants' competency problems. It should be noted that the right time allocation to discuss material that requires demonstration, simulation, or practicum, so that instructors and facilitators can provide learning experiences as planned in the design of the training program for headmaster candidates.

The evaluation of participants' learning outcomes before participating in the training and after attending the training there is an increase, as evidenced by the score before the training with the score after following the training there is a significant difference, judged good or right, this indicates that the learning experience is good or appropriate, but it still needs to be improved for the better.

Use of Cube Evaluation Model 3 Dimensions in program evaluation studies allows evaluators to assess aspects of learning. The dimensions of instruction and institution in the learning system are interrelated unity in the achievement of competencies in knowledge, attitudes, and skills.

Changes in behavior after training and returning to school include the application of the five competencies of the principal, the results of which are concluded to be adequate. The impact of 
the education and training of prospective school principals includes the quality of work, the quality of the school, the accuracy of work, good / adequate.

\section{Recommendation}

1. For the Head of the Education Quality Guaranty Institution (LPMP), it is recommended that education programs for headmaster candidates are needed in improving the competency of school principals as well as the quality of schools. LPMP need to prepare adequate components in relation to the instructional and institutional dimensions of learning. Behavioral knowledge, attitudes, and skills need to be improved by taking into account the indicators of effective success.

2. The person in charge of the training program for headmaster candidates should always carry out evaluations in the context of planning, implementing and evaluating the program including instructors involved in providing learning experiences, to see the gaps that occur in the implementation of the program as a whole.

3. The organizer of the headmaster candidates' training program consisting of a team of instructors and facilitators needs to find the latest literature on training strategies needed to meet the training needs that are held to motivate the participants' learning spirit. The affirmation of education and training rules needs to be improved to be followed by participants, cleanliness of training rooms, consumption space during implementation needs to be improved.

4. Training instructors and facilitators need to review varied methods, media, and strategies in providing learning experiences, so that training participants are more active and creative in participating in training. The use of time allocation during training needs to be refined to suit the material discussed, so that maximum completeness can be achieved.

5. Training participants who achieve less grades should repeat the material that has not been mastered to get the minimum standard completeness set and not forced. This is needed in order to gain mastery of competent candidates for qualified principals, and not just complete the training program for prospective school principals.

6. For the Office of Education and Institutions related to the appointment of the position of headmaster, strict selection with the competency test of the principal is needed. Given the long lag after training with the opportunity to appoint as headmaster, use procedures that are transparent and accountable which aims to standardize the principal, not the interests of certain parties.

7. For the school itself, organizing the training of prospective school principals is one of the efforts to improve the feasibility standard according to the demands of national education standards, and have an impact on improving the quality of quality schools.

8. Blended application Kirkpatrick's evaluation model with 3-dimensional cubes in this evaluation study blends and complements each other so that it becomes a harmonious combination of models. Kirkpatrick's evaluation model as the main model is complemented by the Hammond 3dimensional cube model with cells that detail the aspects of behavior, instruction, and institution.

\section{REFERENCES}

Aiken, Lewis R., dan Gary Groth-Marnat. (2009). Pengetesan dan Pemeriksaan Psikologi. Terjemahan Hartati Widiastuti S.S. PT Indeks.

Azwar, Saifuddin. (2012). Penyusunan Skala Psikologi.Yogyakarta: Pustaka Pelajar.

Denzin, Norman K. dan Yvonna S. Lincoln. (2009). Handbook of Qualitative Reserarch. terjemahan Dariyatno dkk. Yogyakarta: Pustaka Pelajar.

92 | JISAE. Volume 6 Number 1 February 2020. 
Ghony, M. Djuanaidi dan Fauzan Almanshur. (2012). Metodologi Penelitian Kualitatif. Jogjakarta: Ar-Ruzz Media.

James H. Stronge, Holly B. Richard, dan Nancy Catano. (2013). Kualitas Kepala Sekolah yang Efektif, terjemahan Siti Mahyuni. Jakarta: Indeks.

Kirkpatrick, Donald L., dan James D. Kirkpatrick. (2005). Evaluating Training Programs. San Fransisco: Bernett-Koehler Publishers, Inc.

Patton, Michael Quinn. (1990). Qualitative Evaluation and Research Methods. California: Sage Publications, Inc.

Peraturan Menteri Pendidikan dan Kebudayaan RI Nomor 13 Tahun 2007 tentang Standar Kompetensi Kepala Sekolah.

Siswandari. (2013). Petunjuk Pelaksanaan Pemerolehan Nomor Unik. Surakarta: Lembaga Pengembangan dan Pemberdayaan Kepala Sekolah.

Wahjosumidjo. (2008). Kepemimpinan Kepala Sekolah. Jakarta: Raja Grafindo Persada.

Worten, Blaine R., James R. Sanders, dan Jodi L. Fitzpatrick. (2011). Educational Evaluation: Alternative Approach and Practical Guidelines. New York \& London: Longman Publishers. 